\title{
PENERAPAN MODEL MIND MAPPING UNTUK MENINGKATKAN PENGUASAAN KONSEP IPA DI SEKOLAH DASAR
}

\author{
Yuyu Hendawati, Suci Utami Putri, Suko Pratomo, Fitri Widianingsih \\ Pendidikan Guru Sekolah Dasar, Universitas Pendidikan Indonesia, Kampus Purwakarta
}

\section{Kata Kunci :}

Model Mind Mapping Penguasaan Konsep Pembelajaran IPA
Email penulis:

yuyuhendawati@upi.edu

\begin{abstract}
This research is motivated by the lack of mastery of student concept examined from result of evaluation of mastery of concept. Research in general aims to know the activity and mastery of the concept of learning in the science of style materials by applying the model of Mind Mapping. The type of research used is Classroom Action Research with spiral reflection system design. Research carried out in III cycle, which consists of 4 stages of planning, action, observation and reflection. Subject of this research is fourth grader of elementary school in Subang Regency as many as 20 students. Instrument used in the form of test ability of mastery of concept (pretes and postes) and observation sheet (student and teacher). This research concludes that by applying Mind Mapping model can improve mastery of student concept on science learning material. This research is expected to be useful for the development of the education, especially in science learning in elementary school.
\end{abstract}

\begin{abstract}
ABSTRAK
Penelitian ini dilatarbelakangi dengan penguasaan konsep siswa masih rendah, terlihat dari hasil evaluasi penguasaan konsep. Penelitian secara umum bertujuan untuk mengetahui aktivitas dan penguasaan konsep dalam pembelajaran IPA materi gaya dengan menerapkan model pembelajaran Mind Mapping. Jenis penelitian yang digunakan adalah Penelitian Tindak Kelas (PTK) dengan sistam spiral refleksi design. Penelitian dilaksanakan III siklus, yang terdiri dari 4 tahapan yaitu perencanaan, tindakan, observasi dan refleksi. Subjek dari penelitian ini adalah siswa kelas IV SD di Kab. Subang sebanyak 20 siswa. Instrument yang digunakan berupa tes kemampuan penguasaan konsep (pretes dan postes) serta lembar observasi (siswa dan guru). Penelitian ini berkesimpulan bahwa dengan menerapkan model Mind Mapping dapat meningkatkan penguasaan konsep siswa pada pembelajaran IPA materi gaya. Penelitian ini diharapkan dapat bermanfaat bagi perkembangan dunia pendidikan, khususnya pada pembelajaran IPA di Sekolah Dasar.
\end{abstract}

\section{PENDAHULUAN}

Pembelajaran merupakan proses interaksi siswa dengan guru dan sumber belajar pada suatu lingkungan belajar. Komara (2014, hlm. 29) mengemukakan bahwa pembelajaran merupakan bantuan yang diberikan pendidik agar dapat terjadi proses perolehan ilmu dan pengetahuan, penguasaan, kemahiran dan tabiat serta pembentukan sikap dan keterampilan. 
Pembelajaran IPA tidak hanya menuntut siswa untuk mengembangkan kemapuan kognitif saja, akan tetapi siswa juga meningkatkan kemampuan lainnya, salah satunya kemampuan dalam menguasai konsep.

Berdasarkan wawancara tidak terstruktur yang dilakukan di SDN Ganda Manah dengan wali kelas IV pada hari Senin, 17 April 2017 bahwa berdasarkan Kriteria Ketuntasan Minimal (KKM) IPA yang ditetapkan sekolah yaitu minimal 7,0. Siswa yang telah mencapai KKM adalah 7 orang atau $35,00 \%$ dan siswa yang belum lulus ada 13 orang atau $65,00 \%$. Berdasarkan hasil data tersebut dapat disimpulkan bahwa perolehan nilai siswa masih rendah. Oleh karena itu peneliti melakukan tindakan awal (pretest) yang bertujuan untuk meningkatkan penguasaan konsep siswa pada saat proses pembelajran IPA.

Berdasarkan tes awal penguasaan konsep pada pembelajaran IPA tentang gaya pada siswa kelas V dengan jumlah siswa 20 orang di SDN Ganda Manah Subang, terdapat 8 orang siswa yang mencapai KKM atau bila di persentasikan sekitar 40\% saja yang mencapai KKM yang disyaratkan sebesar 70,0 dengan nilai tertinggi 80 dan nilai terendah 20.

Kondisi ini terjadi karena siswa cukup mengerti meskipun terkadang masih ragu dalam menjelaskan materi, dan jika dilihat pada aspek membuat kesimpulan, siswa masih kurang memberikan gagasan maupun pendapat yang jelas, kemudian pada aspek tanya jawab, siswa cenderung kurang memberikan jawaban yang relevan sehingga cenderung monoton. Terdapat beberapa indikasi permasalahan yang menyebabkan siswa kesulitan dalam Pembelajaran IPA tentang Gaya. Pada umumnya penguasaan konsep siswa masih rendah, terlihat dari hasil evaluasi penguasaan konsep menunjukan masih banyak siswa belum menguasai konsep dalam pembelajaran IPA terutama mengenai materi gaya. Hal ini disebabkan karena siswa tidak terlatih untuk berperan aktif dalam proses pembelajaran.

Dari indikasi di atas penggunaan model pembelajaran dapat mengatasi kesulitan yang dihadapi oleh siswa dan memungkinkan siswa untuk lebih aktif dalam pembelajaran, sehingga dapat berdampak pada peningkatan kemampuan siswa dalam menguasai konsep, salah satunya melalui model Pembelajaran Mind Mapping. Model Mind Mapping ini ditemukan oleh Ariestoteles yang dikembangkan kembali oleh Tony Buzan (Swadarna, 2013; 5).

Mind Mapping atau pemetaan pikiran merupakan cara kreatif bagi tiap pembelajar untuk menghasilkan gagasan, mencatat apa yang dipelajari, atau merencanakan tugas baru (Sileberman, 1996). Penggunaan Mind Mapping lebih menggunakan keterampilan kortikalkata, gambar, nomor, logika, ritme, warna, dan ruang kesadaran dalam suatu cara unik yang kuat sehinnga tidak menimbulkan kejenuhan bagi siswa. Adapun tahapan-tahapan pembelajaran Mind Mapping menurut Swadarma (2013, hlm; 75) memiliki lima tahapan pembelajaran yaitu: 1) Orientasi, 2) penyajian (Konfrontasi), 3) Akomodasi, 4) Transfer.

Dengan menerapkan model Mind Mapping pada saat pembelajaran IPA dalam pokok bahasan Gaya, diharapkan dapat mengatasi kesulitan belajar siswa diantaranya hal yang dapat mengganggu dan menghambat kemampuan penguasaan konsep siswa khusunya pada pembelajran IPA pada pokok bahasan Gaya. Oleh sebab itu, peneliti melakukan penelitian yang berjudul: "Penerapan Model Mind Mapping Untuk Meningkatkan Penguasaan Konsep Siswa Pada Pembelajaran IPA di SD.

Berdasarkan latar belakang diatas, maka perumusan permasalahan dalam penelitian ini adalah "Apakah penerapan model Mind Mapping dapat meningkatkan penguasaan konsep siswa dalam pembelajaran IPA pada materi gaya di SD?"

Secara spesifik pertanyaan penelitian ini adalah, 1) Bagaimana aktivitas siswa dan aktivitas kinerja guru pada saat menerapkan model pembelajaran Mind Mapping pada pembelajaran 
IPA pada materi gaya di SDN Ganda Manah Kecamatan Subang Kabupaten Subang?, dan 2) Bagaimana penguasaan konsep siswa dalam pembelajaran IPA pada materi gaya di SDN Ganda Manah Kecamatan Subang Kabupaten Subang setelah menerapkan model pembelajaran Mind Mapping?

\section{KAJIAN TEORI}

\section{Model Mind Mapping}

Model Mind Mapping menurut Swadarma (2013, hlm;3) merupakan sistem Berpikir yang terpancar (radiant thinking) sehingga dapat mengembangkan ide dan pikiran ke segala arah, divergent, dan melihatnya dari berbagai sudut pandang, selain itu mind mapping merupakan model penulisan yang bekerja dengan menggunakan prinsip manajemen otak sehingga dapat membuka seluruh potensi dan kapasitas otak yang masih tersembunyi.

Sedangkan menurut DePorter (Kusmintaayu, 2012, hlm;100) mengatakan bahwa mind mapping dapat membantu kita mengingat perkataan dan bacaan, meningkatkan pemahaman terhadap materi dan memberikan wawasan baru karena didalamnya memuat kata-kata kunci dalam sebuah topik. Berdasarkan uraian di atas mind mapping dapat disimpulkan mind mapping merupakan bentuk model yang mudah digunakan dan efektif serta mampu membuat siswa lebih aktif dalam pembelajaran baik dalam mengeluarkan informasi,ide maupun gagasan baru utamanya dapat mempermudah siswa untuk menguasai konsep materi ajar yang telah diberikan.

Adapun tujuan mind mapping menurut Trianto (2007, hlm;166) yaitu untuk memperjelas pemahaman suatu bacaan, sehingga dapat dipakai sebagai alat evaluasi dengan cara membantu siswa untuk membaca peta konsep dan menjelaskan hubungan antara konsep satu dengan yang lainnya dalam satu peta konsep. Tahapan-tahapan pembelajaran Mind Mapping menurut Swadarma (2013, hlm; 75) memiliki lima tahapan pembelajaran yaitu: 1) Orientasi, 2) pelacakan, 3) penyajian (Konfrontasi), 4) inkuiri, 5) Akomodasi, 4) Transfer.

Menurut Swadarna (2013, hlm; 9) mengatakan bahwa kelebihan model mind mapping dapat meningkatkan kinerja otak, memacu kreativitas, sederhana dan mudah dikerjakan, menarik dan mudah tertangkap oleh mata (eye catching), dapat melihat sejumlah data dengan mudah, sewaktu-waktu siswa dapat me -recall data yang ada dengan mudah.

Selain memiliki kelebihan, mind mapping juga memiliki beberapa kekurangan, diantaranya menurut Shoimin $(2014$, hlm; 107) yaitu hanya siswa yang aktif saja yang terlibat, tidak seluruh siswa belajar dan ada saling mengandalkan teman, jumlah detail informasi tidak dapat dimasukan.

\section{Penguasaan Konsep}

\section{a. Pengertian Penguasaan Konsep}

Konsep merupakan dasar dari sebuah teori. Sebuah konsep muncul dari fakta-fakta yang telah ada sebelumnya. Mempelajari konsep artinya menghubungkan fakta-fakta menjadi sebuah kesatuan yang lebih rasional. Gagne (Wisudawati, 2013, hlm. 32) mengungkapkan bahwa belajar merupakan kegiatan yang kompleks yang menghasilkan kapabilitas, timbulnya kapabilitas tersebut disebabkan stimulasi yang berasal dari lingkungan dan proses kognitif yang merupakan proses pembentukan konsep yang disebabkan oleh prosese kognitif mengenai apa yang sudah ada di lingkungan. Penguasaan konsep terdiri dari dua kata yaitu penguasaan dan konsep. Penguasaan menurut Kamus Besar Bahasa Indonesia (2005, hlm. 604) diartikan sebagai pemahaman atau kesanggupan untuk menggunakan pengetahuan, dan kepandaian. 


\section{b. Indikator Penguasaan Konsep}

Sumaya (2004, hlm. 102) mengemukakan indikator penguasaan konsep yaitu seseorang dapat dikatakan menguasai konsep jika orang tersebut benar-benar memahami konsep yamg dipelajarinya sehingga mampu menjelaskan dengan menggunakan kata-kata sendiri sesuai dengan pengetahuan yang dimilikinya, akan tetapi tidak mengubah makna yang ada di dalamnya.

Indikator yang lebih komprhjensif dikemukakan oleh bloom yang dikutip oleh Rustaman (2005, hlm. 23) bahwa indikator penguasaan konsep dari C1-C6. Dari indikator tersebut pada penelitian ini hanya beberapa indikator yang digunakan yang telah disesuaikan dengan model pembelajaran Mind Mapping diantaranya yaitu C2, C4, dan C6.

\section{Keterkaitan Mind Mapping dengan Penguasaan Konsep}

Menurut Arnyana (2007;675) keterkaitan antara Mind Mapping dengan penguasaan konsep diantaranya dalam hal pencatatan untuk meningkatkan daya ingat siswa, maka dari itu Mind Mapping menggunakan pengingat-pengingat visual dan sensorik dalam suatu pola dari ideide yang berkaitan atau berhubungan seperti jalan yang digunakan untuk belajar. Mind Mapping merupakan model mencatat yang unik dan mudah digunakan yang dapat membantu mengingat perkataan, bacaan, meningkatkan pemahaman terhadap materi dan mampu meningkatkan penguasaan konsep siswa, sehingga model ini sangat erat kaitannya dan merupakan model yang tepat untuk meningkatkan kemampuan penguasaan konsep siswa.

\section{Pembelajaran IPA di SD}

\section{a. Pengertian Pendidikan IPA}

Pendidikan Ilmu Pengatahuan Alama (IPA) berdasarkan kurikulum KTSP 2006 merupakan salah satu mata pelajaran yang diajarkan daam jenjang pendidikan sekolah dasar. Samatowa (2011, hlm; 3) berpendapat bahwa IPA membahas tentang gejala-gejala alam yang disusun secara sistematis yang didasarkan kepada hasil percobaan dan hasil pengamatan yang dilakukan oleh manusia. IPA dalam penerapannya secara umum terbatas pada gejala-gejala alam, lahir dan berkembang melalui metode ilmiah seperti percobaan dan pengamatan.

\section{b. Tujuan Pembelajaran IPA di Sekolah Dasar}

Tujuan pembelajaran IPA di Sekolah Dasar menurut Mulyasa (2011, hlm; 11) mengungkapkan bahwa siswa dapat memiliki kemampuan sebagai berikut: 1) Mengembangkan rasa ingin tahu, sikap positif dan kesadaran adanya hubungan yang saling mempengaruhi antara IPA dengan lingkungan disekitarnya. 2) Mengembangkan pengetahuan dan penguasaan konsep-konsep IPA yang bermanfaat dan dapat diterapkan dalam kehidupan sehari-hari.

\section{METODE PENELITIAN}

Penelitian ini dikembangkan dengan menerapkan metode Penelitian Tindakan Kelas (PTK). Desain penelitian digunakan adalah desain penelitian yang dilakukan oleh Kemmis dan Mc. Taggart yang terdiri dari empat komponen, yaitu perencanaan, tindakan, observasi dan refleksi. Keempat komponen tersebut dianggap satu siklus.

Penelitian dilaksanakan di SDN Ganda Manah Kecamatan Cikampek Kabupaten Karawang. Subjek penelitian seluruh siswa kelas IV yang terdiri dari 20 siswa, yaitu 13 orang siswa perempuan dan 7 orang siswa laki-laki. Penelitian ini menggunakan instrumen penilaian yang berupa tes kemampua konsep, lembar observasi dan dokumentasi. 
Analisis data dalam penelitian ini dilakukan dengan mengolah data yang berasal dari lembar observasi dan lembar tes. Langkah analisis data dilakukan sebagai berikut:

Untuk mengolah data yang bersifat kualitatif yaitu hasil observasi guru dan siswa digunakan skala 1 sampai 4 dengan interpensi, $1=$ Kurang $\quad 3=$ baik, $2=$ Cukup , $4=$ Sangat baik, Selanjutnya setiap siklus diambil rata-rata persentasenya dengan rumus sebagai berikut :

$$
P=\frac{S}{N} \times 100
$$

Keterangan: $\mathrm{P}=$ Persentasi pelaksanaan setiap tahapan Mind Mapping

$\mathrm{S}=$ Jumlah skor, $\mathrm{N}=$ Jumlah skor total maksimal. Data dikonversikan kedalam bentuk berikut: Keterangan : $\mathrm{A}=3,1-4$ Sangat Baik, $\mathrm{B}=2,1-3$, Baik, $\mathrm{C}=1,1-2$ Cukup.

Sementara, perhitungan kriteria Ketuntasan nilai Minimal (KKM) siswa pada mata pelajaran IPA yaitu 70 Untuk siswa dinyatakan tuntas apabila siswa tersebut mencapai KKM.

Menurut Trianto (2007, hlm.241) acuan yang dipakai dalam mengukur kebeerhasilan tindakan kelas adalah persentase nilai ketuntasan belajar siswa $\geq 70$ secara klasikal mencapai $85 \%$. Untuk menghitung ketuntasan belajar secara klasikal, dapat digunakan rumus Daya Serap Klasikal sebagai berikut:

Persentase Daya Serap Klasikal $=\frac{\text { Jumlah siswa yang mencapai KKM }(\geq 70)}{\text { Jumlah seluruh siswa }} \times 100 \%$

Jika nilai ketuntasan belajar siswa $\geq 70$ secara klasikal mencapai $85 \%$ maka penelitian ini dinyatakan berhasil. Hal ini mengacu kepada Depdikbud (Sohimin, 2006, hlm. 14) yang menyatakan bahwa:

Siswa dinyatakan tuntas belajarnya (ketuntasan individu) jika proposi jawaban benar siswa $\geq 70$ dan suatu kelas dikatakan tuntas belajarnya (ketuntasan klasikal) jika dalam kelas tersebut terdapat $\geq 85 \%$ siswa yang telah tuntas belajarnya.

\section{HASIL DAN PEMBAHASAN \\ Deskripsi Pelaksanaan Tindakan}

Pelaksanaan tindakan berupa implementasi tindakan-tindakan yang telah direncanakan sebelumnya berkaitan dengan model Mind Mapping. Sebelum di terapkannya model pembelajaran yang akan dilakukan dalam penelitian tindakan kelas ini, peneliti melakukan wawancara tidak terstruktur yang dilakukan dengan wali kelas IV pada hari Senin, 17 April 2017.

Pada awal didapat hasil observasi dan wawancara diketahui bahwa pembelajaran IPA tentang materi gaya di kelas IV belum menerapkan model pembelajaran yang bervariasi. Cara mengajar guru hanya dengan metode ceramah yang didominasi oleh guru, lalu diselingi dengan tanya jawab. Setelah itu siswa mengerjakan soal latihan yang dibuat oleh guru. Siswa belum terlibat aktif dalam pembelajaran, karena hanya duduk, dengar, catat dan diam. Siswa cepat bosan dan kurang fokus pada pelajaran. Hal ini berakibat pada kurangnya penguasaan siswa pada pembelajaran IPA tentang konsep gaya.

Hasil pretest penguasaan konsep gaya siswa kelas IV SDN Ganda Manah sebelum tindakan disajikan dalam tabel 1. 
Tabel .1 Daftar Nilai Awal (Pretest) Sebelum Menggunakan Model Mind Mapping

\begin{tabular}{|c|c|c|c|c|c|}
\hline No & Frekuensi & Skor & Nilai & KKM & $\begin{array}{c}\text { Kategori } \\
\text { Ketuntasan } \\
\text { (L/TL) }\end{array}$ \\
\hline 1 & 3 Siswa & $1(3)$ & $20(60)$ & \multirow{5}{*}{70} & TL \\
\hline 2 & 5 Siswa & $2(10)$ & $40(200)$ & & $\mathrm{TL}$ \\
\hline 3 & 4 Siswa & $3(12)$ & $60(240)$ & & $\mathrm{TL}$ \\
\hline 4 & 8 Siswa & $4(24)$ & $80(320)$ & & $\mathrm{L}$ \\
\hline \multicolumn{2}{|l|}{ Jumlah } & 49 & 820 & & \\
\hline \multicolumn{2}{|c|}{ Rata-rata } & \\
\hline \multicolumn{2}{|c|}{ Persentase } & \\
\hline
\end{tabular}

Dari Tabel 4.1 dapat dilihat bahwa terdapat 8 orang siswa yang mencapai KKM atau bila di persentasikan sekitar $40 \%$ saja yang mencapai KKM yang disyaratkan sebesar 70,0 dengan nilai tertinggi 80 dan nilai terendah 20, dari 20 siswa kelas IV yang mencapai KKM

\section{Temuan Pelaksanaan Tindakan}

Siklus I

Pada pelaksanaan tindakan untuk siklus I, proses pembelajaran Ilmu Pengetahuan Alam (IPA) di kelas IV SDN Ganda Manah Kecamatan Subang Kabupaten Subang yaitu diawali dengan menganalisis materi ajar mengenai materi gaya yang akan dijadikan sebagai bahan pembelajaran dengan menerapkan model mind mapping.

Berdasarkan pada tindakan siklus I hasil lembar observasi yang diperoleh dari lembar pengamatan yang didalamnya terdapat hasil pengamatan yang dilakukan oleh peneliti terhadap 20 orang siswa dan pengamatan tersebut dilakukan pada tiap individu tidak berkelompok dapat dilihat pada tabel 2 .

Tabel 2. Lembar Observasi Aktivitas Siswa Siklus I

\begin{tabular}{|c|c|c|c|c|c|c|}
\hline No & Aspek yang diamati & 氖 & 郶 & 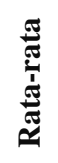 & 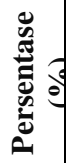 & $\stackrel{\Xi}{0}$ \\
\hline A & Kegiatan Awal : Tahap Orientasi & & & & & \\
\hline 1 & $\begin{array}{l}\text { Memberikan gagasan dengan jelas dan menjawab pertanyaan dengan } \\
\text { benar. }\end{array}$ & 4 & 64 & 3,2 & $\begin{array}{l}3,2 \\
\%\end{array}$ & A \\
\hline $\mathrm{B}$ & Kegiatan Awal : Tahap Pelacakan & & & & & \\
\hline 2 & $\begin{array}{l}\text { Dapat mengahasilkan gagasan (kata kunci untuk mapping), jawaban } \\
\text { atau pertanyaan yang bervariasi. }\end{array}$ & 3 & 57 & $\begin{array}{c}2,8 \\
5\end{array}$ & $\begin{array}{l}2,8 \\
5 \\
\%\end{array}$ & $\mathrm{~B}$ \\
\hline $\mathrm{C}$ & Kegiatan Inti:Tahap Konfrontasi, Inkuiri, akomodasi & & & & & \\
\hline 3 & $\begin{array}{l}\text { Dapat melakukan percobaan dengan baik bersama teman kelompoknya } \\
\text { dan memberikan jawaban yang berbeda dengan orang lain serta } \\
\text { membuat Mapping hasil sendiri yang berbeda dengan orang lain. }\end{array}$ & 8 & 65 & $\begin{array}{c}3,2 \\
5\end{array}$ & $\begin{array}{l}3,2 \\
5 \\
\%\end{array}$ & A \\
\hline $\mathrm{D}$ & Kegiatan inti :Tahap Transfer & & & & & \\
\hline 4 & $\begin{array}{l}\text { Dapat memberikan jawaban, gagasan dengan cermat serta dapat } \\
\text { mengembangkan gagasan baik dari diri sendiri maupun dari orang lain }\end{array}$ & 5 & 66 & 3,3 & $\begin{array}{l}3,3 \\
\%\end{array}$ & A \\
\hline & Jumlah skor & 20 & \multicolumn{4}{|l|}{252} \\
\hline & Rata-rata & \multicolumn{5}{|l|}{63} \\
\hline
\end{tabular}




$$
\begin{gathered}
P=\frac{S}{N} \times 100= \\
\frac{252}{320} \times 100=78,75 \\
78,75 \%
\end{gathered}
$$

\section{Refleksi siklus I}

Berdasarkan hasil pengamatan observer, aktivitas siswa menunjukan bahwa masih terdapat beberapa siswa yang belum terbiasa dengan model pembelajaran Mind Mapping pada saat proses pembelajaran berlangsung. Terdapat siswa yang masih ragu dalam bertanya dan memberikan gagasan, maupun pendapat yang relevan dan masih terdapat beberapa siswa yang belum bisa menyesuaikan gambar atau simbol serta kata kunci dengan materi ajar (gaya gravitasi). Berdasarkan nilai rata-rata observasi aktivitas siswa secara keseluruhan mencapai 63 dan termasuk ke dalam kategori baik.

Guru harus membuat perencanaan kembali untuk meningkatkan penguasaan konsep siswa pada tindakan siklus berikutnya. Guru harus menyusun Rencana Pelaksanaan Pembelajaran dan Lembar Kerja Siswa yang lebih mengarah pada proses pembelajaran yang kreatif sehingga pada tindakan siklus selanjutnya bisa lebih baik dari pada tindakan siklus I.

Siklus II

Pada perencanaan tindakan untuk siklus II dilaksankan berdasarkan hasil kajian terhadap refleksi pada tindakan siklus II. pada siklus II dibuat kembali perencanaan pembelajaran, pembelajaran Ilmu Pengetahuan Alam (IPA) di kelas IV SDN Ganda Manah Kecamatan Subang Kabupaten Subang yaitu diawali dengan menganalisis materi ajar mengenai materi gaya.

Hasil lembar observasi yang dilaksakana pada siklus II diperoleh dari lembar pengamatan.. Pada lembar observasi aktivitas siswa terdapat 4 aspek dan pada lembar observasi aktivitas pembelajaran guru terdapat 8 aspek yang diamati oleh peneliti, semua aspek tersebut telah disesuaikan dengan indikator Berpikir kreatif serta dengan langkah-langkah dari model Mind Mapping.. Untuk mengetahui aktivitas belajar siswa melalui penerapan model Mind

\begin{tabular}{|c|c|c|c|c|c|}
\hline No & Aspek yang diamati & . & 恋 & 莺 & 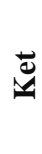 \\
\hline A & Berpikir Lancar (Kegiatan Awal : Tahap Orientasi) & & & & \\
\hline 1 & $\begin{array}{l}\text { Memberikan gagasan dengan jelas dan menjawab } \\
\text { pertanyaan dengan benar. }\end{array}$ & 4 & 72 & 3,6 & $\mathrm{~A}$ \\
\hline B & Berpikir Luwes (Kegiatan Awal : Tahap Pelacakan & & & & \\
\hline 2 & $\begin{array}{l}\text { Dapat mengahasilkan gagasan (kata kunci untuk } \\
\text { mapping), jawaban atau pertanyaan yang bervariasi. }\end{array}$ & 5 & 76 & 3,8 & A \\
\hline $\mathrm{C}$ & $\begin{array}{l}\text { Berpikir Orisinil (Kegiatan Inti:Tahap } \\
\text { Konfrontasi, Inkuiri, akomodasi ) }\end{array}$ & & & & \\
\hline
\end{tabular}
Mapping dalam materi gaya (gaya gesek) pada siklus Idapat dilihat pada Tabel 3.

Tabel 3. Lembar Observasi Aktivitas Siswa Siklus II 


\begin{tabular}{|c|c|c|c|c|c|}
\hline No & Aspek yang diamati & 窇- & 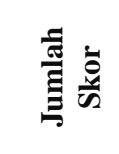 & 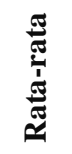 & $\begin{array}{l}\overrightarrow{0} \\
\vec{v}\end{array}$ \\
\hline 3 & $\begin{array}{l}\text { Dapat melakukan percobaan dengan baik bersama } \\
\text { teman kelompoknya dan memberikan jawaban yang } \\
\text { berbeda dengan orang lain serta membuat Mapping } \\
\text { hasil sendiri yang berbeda dengan orang lain. }\end{array}$ & 5 & 77 & 3,85 & A \\
\hline $\mathrm{D}$ & Berpikir Terperinci (Krgiatan inti :Tahap Transfer) & & & & \\
\hline 4 & $\begin{array}{l}\text { Dapat memberikan jawaban, gagasan dengan } \\
\text { cermatserta dapat mengembangkan gagasan baik } \\
\text { dari diri sendiri maupun dari orang lain }\end{array}$ & 6 & 80 & 4.0 & A \\
\hline \multicolumn{2}{|c|}{ Jumlah skor } & 20 & \multicolumn{3}{|l|}{305} \\
\hline \multicolumn{2}{|c|}{ Rata-rata } & \multicolumn{4}{|l|}{76,25} \\
\hline \multirow{2}{*}{\multicolumn{2}{|c|}{ Persentase klasikal (\%) }} & \multicolumn{4}{|c|}{$P=\frac{S}{N} \times 100=\frac{305}{320} \times 100=95,31$} \\
\hline & & \multicolumn{4}{|c|}{$95,31 \%$} \\
\hline
\end{tabular}

\section{Refleksi Siklus II}

Berdasarkan hasil pengamatan peneliti, aktivitas siswa menunjukan bahwa siswa sudah mulai terbiasa dengan model pembelajaran Mind Miapping walaupun masih ada beberapa siswa yang belum terbiasa dengan model pembelajaran Mind Mapping hal ini dapat dilihat dari siswa yang mendapatkan nilai di atas KKM pada siklus I terdapat 16 siswa dan 4 siswa yang nilainya dibawah KKM sedangkan pada siklus II terdapat 17 siswa yang nilainya telah mencapai KKM dan 3 orang siswa yang masih dibawah KKM. Pada saat proses pembelajaran berlangsung terdapat siswa yang masih ragu dalam bertanya dan kurang dalam menguasai konsep materi yang telah dipaparkan serta masih terdapat beberapa siswa yang belum bisa menyesuaikan gambar atau simbol serta kata kunci dengan materi ajar (gaya gravitasi). Berdasarkan nilai rata-rata observasi aktivitas siswa secara keseluruhan pada siklus I mencapai 63 dan termasuk ke dalam kategori baik sedangkan pada siklus II mencapai 76,25 termasuk dalam kategori sangat baik. Adapun hasil nilai evaluasi penguasaan konsep yang diperoleh oleh siswa secara keseluruhan pada siklus I mencapai 74,45 dan termasuk dalam kategori , sedangkan pada siklus II mencapai 87,5 dan termasuk pada kategori A yang berarti sangat baik. Adapun hasil nilai evaluasi penguasaan konsep siswa pada siklus I berdasarkan ketuntasan belajar klasikal (DSK) mencapai $80 \%$ dan pada siklus II berdasarkan ketuntasan belajar klasikal (DSK) mencapai 95\%. Dalam siklus I dan II tujuan pembelajaran sudah cukup baik, dapat dilihat pada siklus I terdapat 4 orang yang belum tuntas mencapai KKM dan pada siklus II terdapat 3 orang yang belum tuntas mencapai KKM yang telah ditentukan oleh sekolah yaitu $\geq 70$.

Guru harus membuat perencanaan kembali untuk meningkatkan penguasaan konsep siswa pada tindakan siklus berikutnya. Guru harus menyusun Rencana Pelaksanaan Pembelajaran dan Lembar Kerja Siswa yang lebih mengarah pada proses pembelajaran yang kreatif sehingga pada tindakan siklus selanjutnya bisa lebih baik dari pada tindakan siklus I dan siklus II.

\section{Siklus III}

Pada perencanaan tindakan untuk siklus III dilaksankan berdasarkan hasil kajian terhadap refleksi pada tindakan siklus III. pada siklus III dibuat kembali perencanaan pembelajaran, 
pembelajaran Ilmu Pengetahuan Alam (IPA) di kelas IV SDN Ganda Manah Kecamatan Subang Kabupaten Subang.

Hasil lembar observasi yang dilaksakana pada siklus III diperoleh dari lembar pengamatan. Lembar observasi aktivitas siswa terdapat 4 aspek dan pada lembar observasi aktivitas pembelajaran guru terdapat 8 aspek yang diamati oleh peneliti, semua aspek tersebut telah disesuaikan dengan langkah-langkah dari model Mind Mapping. Untuk mengetahui aktivitas belajar siswa melalui penerapan model Mind Mapping dalam materi gaya (gaya magnet) pada siklus III dapat dilihat pada Tabel 4.

Tabel 4. Lembar Observasi Aktivitas Siswa Siklus III

\begin{tabular}{|c|c|c|c|c|c|}
\hline No & Aspek yang diamati & 总 & 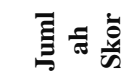 & $\stackrel{\frac{\pi}{\pi}}{\stackrel{\pi}{\pi}}$ & U. \\
\hline A & $\begin{array}{l}\text { Berpikir Lancar (Kegiatan Awal : Tahap } \\
\text { Orientasi) }\end{array}$ & & & & \\
\hline 1 & $\begin{array}{l}\text { Memberikan gagasan dengan jelas dan menjawab } \\
\text { pertanyaan dengan benar. }\end{array}$ & 4 & 77 & 3,85 & A \\
\hline B & $\begin{array}{l}\text { Berpikir Luwes (Kegiatan Awal : Tahap } \\
\text { Pelacakan ) }\end{array}$ & & & & \\
\hline 2 & $\begin{array}{l}\text { Dapat mengahasilkan gagasan (kata kunci untuk } \\
\text { mapping), jawaban atau pertanyaan yang } \\
\text { bervariasi. }\end{array}$ & 5 & 80 & 4,0 & A \\
\hline $\mathrm{C}$ & $\begin{array}{l}\text { Berpikir Orisinil (Kegiatan Inti:Tahap } \\
\text { Konfrontasi, Inkuiri, akomodasi) }\end{array}$ & & & & \\
\hline 3 & $\begin{array}{l}\text { Dapat melakukan percobaan dengan baik bersama } \\
\text { teman kelompoknya dan memberikan jawaban } \\
\text { yang berbeda dengan orang lain serta membuat } \\
\text { Mapping hasil sendiri yang berbeda dengan orang } \\
\text { lain. }\end{array}$ & 6 & 80 & 4,0 & A \\
\hline $\mathrm{D}$ & $\begin{array}{l}\text { Berpikir Terperinci (Kegiatan inti :Tahap } \\
\text { Transfer) }\end{array}$ & & & & \\
\hline 4 & $\begin{array}{l}\text { Dapat memberikan jawaban, gagasan dengan } \\
\text { cermatserta dapat mengembangkan gagasan baik } \\
\text { dari diri sendiri maupun dari orang lain }\end{array}$ & 5 & 80 & 4,0 & A \\
\hline \multicolumn{2}{|c|}{ Jumlah skor } & 20 & \multicolumn{3}{|l|}{317} \\
\hline \multicolumn{2}{|c|}{ Rata-rata } & \multicolumn{4}{|l|}{79,25} \\
\hline \multirow{2}{*}{\multicolumn{2}{|c|}{ Persentase klasikal (\%) }} & \multicolumn{4}{|c|}{$P=\frac{S}{N} \times 100=\frac{317}{320} \times 100=99,06$} \\
\hline & & \multicolumn{4}{|c|}{$99,06 \%$} \\
\hline
\end{tabular}

\section{Pembahasan Hasil Penelitian}

Aktivitas siswa diamati dan dinilai oleh observer dengan mengacu pada tahapan model pembelajaran Mind Mapping dan kemudian nilai akhir dan dari lembar observasi diklasifikasikan berdasarkan kategori yang telah ditetapkan, kategori tersebut meliputi kategori A (Sangat Baik) dengan rentang nilai 3,1 - 4, kategori B (Baik) dengan rentang nilai 2,1-3, kategori $\mathrm{C}$ (Cukup) dengan rentang nilai 1,1-2, dan kategori D (Kurang) dengan rentang nilai 0,1-1. Hasil lembar observasi dapat dilihat pada lampiran. Adapun rekapitulasi nilai observasi terdapat pada tabel 5 .

Tabel 5. Rekapitulasi Nilai Aktivitas Siswa Pada Siklus I, II dan III

\begin{tabular}{|c|c|c|c|c|c|c|c|c|c|}
\hline \multirow[b]{2}{*}{ Tahapan } & \multicolumn{3}{|c|}{ Siklus I } & \multicolumn{3}{|c|}{ Siklus II } & \multicolumn{3}{|c|}{ Siklus III } \\
\hline & 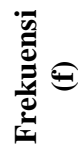 & 节 & 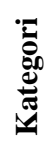 & 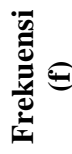 & 苛 & 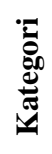 & $\frac{\bar{y}}{\vec{E}}=$ & $\stackrel{\ddot{\bar{t}}}{\bar{z}}$ & تَّت \\
\hline $\begin{array}{l}\text { Kegiatan Awal= } \\
\text { Orientasi }\end{array}$ & 3 & 3,2 & A & 4 & 3,6 & A & 4 & 3,85 & A \\
\hline $\begin{array}{l}\text { Kegiatan Awal= } \\
\text { Pelacakan }\end{array}$ & 3 & 2,85 & B & 5 & 3,8 & A & 5 & 4,0 & A \\
\hline
\end{tabular}




\begin{tabular}{|c|c|c|c|c|c|c|c|c|c|}
\hline \multirow[b]{2}{*}{ Tahapan } & \multicolumn{3}{|c|}{ Siklus I } & \multicolumn{3}{|c|}{ Siklus II } & \multicolumn{3}{|c|}{ Siklus III } \\
\hline & 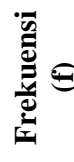 & 嵒 & 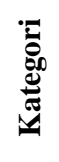 & 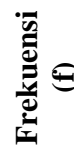 & $\overline{\vec{z}}$ & 离 & 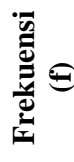 & $\frac{\tilde{\pi}}{\bar{z}}$ & 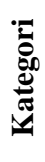 \\
\hline $\begin{array}{l}\text { Kegiatan Inti = } \\
\text { Konfrontasi, } \\
\text { Inkuiri, dan } \\
\text { Akomodasi }\end{array}$ & 8 & 3,25 & A & 5 & 3,85 & $\mathrm{~A}$ & 6 & 4,0 & A \\
\hline $\begin{array}{l}\text { Kegiatan inti = } \\
\text { Transfer }\end{array}$ & 5 & 3,3 & A & 6 & 4,0 & A & 5 & 4,0 & A \\
\hline
\end{tabular}

Sumber : Data yang diolah (2017)

\section{Penguasaan Konsep Siswa pada Kelas IV dalam Pembelajaran IPA setelah Menerapkan Model Pembelajrana Mind Mapping.}

Penguasaan konsep siswa kelas IV SDN Ganda Manah pada pembelajaran IPA dengan menggunkan model Mind Mapping pada materi gaya dari hasil post test yang dicapai peserta didik menunjukan peningkatan yang signifikan dan terbukti dapat meningkatkan penguasaan konsep siswa pada pembelajaran IPA materi gaya dapat dilihat dari hasil nilai evaluasi penguasaan konsep siswa dari tiap siklusnya. Peningkatan rata-rata penguasaan konsep dan persentase ketuntasan belajar siswa pada siklus I,II dan III dapat dilihat pada tabel 6 .

Tabel 6. Rekapitulasi Nilai Evaluasi Penguasaan Konsep Kelas IV Pada Siklus I, II dan III

\begin{tabular}{|c|c|c|c|c|}
\hline \multirow{2}{*}{ Siklus } & \multicolumn{3}{|c|}{ Jumlah Skor Pada } & \multirow{2}{*}{ Keterangan } \\
\cline { 2 - 4 } & $\begin{array}{c}\text { Jumlah } \\
\left(\sum\right)\end{array}$ & $\begin{array}{c}\text { Rata- } \\
\text { rata }(\mathbf{X})\end{array}$ & $\begin{array}{c}\text { Persentase } \\
\text { DSK }(\%)\end{array}$ \\
\hline Siklus I & $\mathbf{1 4 8 9}$ & $\mathbf{7 4 , 4 3}$ & $\mathbf{8 0 \%}$ & KKM Tercapai \\
\hline Siklus II & $\mathbf{1 7 5 0}$ & $\mathbf{8 7 , 5}$ & $\mathbf{8 5 \%}$ & KKM Tercapai \\
\hline Siklus III & $\mathbf{1 8 5 0}$ & $\mathbf{9 2 , 5}$ & $\mathbf{9 5 \%}$ & KKM Tercapai \\
\hline \multicolumn{4}{|c|}{ Sumber : Data yang diolah (2017) } \\
\hline
\end{tabular}

Untuk mendapatkan gambaran yang lebih jelas mengenai peningkatan nilai evaluasi penguasaan konsep siswa pada siklus I, II dan III dapat dilihat pada gambar 1

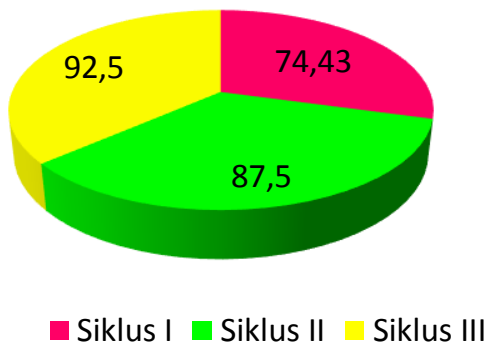

Gambar 1. Rekapitulasi Nilai Evaluasi Penguasaan konsep Siswa Kelas IV Pada Siklus I, II dan III

Salah satu dampak positif dengan menerapkan model pembelajaran Mind Mapping ini yaitu pada suasana dan rasa antusias siswa pada proses pembelajaran. pembelajaran yang kurang efektif, teknik mencatat yang kurang kreatif dan sulitnya memahami suatu konsep pada suatu topik bahasan membuat minat belajar siswa menjadi menurun, maka dari itu guru (peneliti) menerapkan model pembelajaran Mind Mapping ini sebagai solusi dari permasalahan tersebut, dan terbukti bahwa model pembelajaran ini cukup efektif digunakan dalam 
pembelajaran utamanya pada pembelajaran IPA tentang gaya. Hal ini merajuk pada pendapat Trianto (2007, hlm; 166) bahwa Mind Mapping dapat membantu memperjelas pemahaman suatu bacaan, sehingga dapat dipakai sebagai alat evaluasi untuk membantu siswa untuk membaca peta konsep dan menjelaskan hubungan antara konsep satu dengan yang lainnyadalam satu peta konsep, dan berdampak pada peningkatan penguasaan konsep. Hal ini dibuktikan dari hasil rata-rata yang diperoleh siswa pada setiap siklusnya sebagai berikut:

a. Hasil penguasaan konsep rata-rata yang diperoleh pada siklus pertama 74,43 terjadi peningkatan pada siklus ke II mencapai 87,5 . Peningkatan dari siklus I sampai siklus II terjadi peningkatan sebanyak 13,07.

b. Hasil penguasaan konsep rata-rata yang diperoleh pada siklus II 87,5 terjadi peningkatan pada siklus ke III mencapai 92,5. Peningkatan dari siklus I sampai siklus III terjadi peningkatan sebanyak 18,07.

Berdasarkan data diatas pada saat menerapkan model pembelajaran Mind Mapping dalam pembelajaran IPA tentang gaya terdapat peningkatan pada setiap siklusnya. Hal ini merupakan bukti bahwa dengan menerapkan model Mind Mapping dapat meningkatkan penguasaan konsep siswa pada materi gaya. Peningkatan yang terjadi disebabkan karena adanya keterlibatan siswa selama proses pembelajaran telah diberikan kesempatan untuk untuk mengajukan pertanyaan yang variatif serta melakukan percobaan perihal gaya dan juga kesempatan untuk mengungkapkan pendapat, gagasan maupun ide kreatif siswa sehingga dapat membantu siswa pada saat menjelaskan suatu konsep dan berdampak pada peningkatan penguasaan konsep siswa.

Kesempatan untuk mengungkapkan pendapat, gagasan maupun dalam hal pencatatan pada saat mencata materi ajar siswa dapat menggunakan gambar, simbol, dan variasi warna yang dapat membantu siswa untuk mengingat dan memahami suatu konsep dalam satu topic bahasan sehingga siswa memiliki peluang untuk meningkatkan penguasaan konsepnya pada saat memecahkan masalah dari suatu permasalahan serta dapat memberikan kesan tersendiri bagi siswa sehingga proses pembelajaran menjadi lebih bermakna pernyataan tersebut sesuai dengan pernyataan Swadarna (2013, hlm;39) mengemukakan bahwa pembelajaran dengan menggunkana model Mind Mapping dapat memberikan banyak hal yang berkaitan dengan kemampuan penguasaan konsep yang dapat dijadikan sebagi unsur penguat (reinforcement) belajar seperti, menggambar, mewarnai, memberi key images, sehingga proses pembelajaran dapat kondusif, fun, dan reward.

\section{KESIMPULAN}

Berdasarkan hasil penelitian dan pembahasan pada proses pembelajaran IPA dengan menerapkan model pembelajran Mind Mapping untuk meningkatkan penguasaan konsep siswa pada materi gaya, maka diperoleh kesimpulan, pertama, aktivitas siswa dengan menggunakan model Mind Mapping untuk meningkatkan penguasaan konsep pada saat pembelajaran IPA materi gaya di SDN Ganda Manah Kecamatan Subang Kabupaten Subang mengalami peningkatan. Hal tersebut dapat dilihat dari peningkatan hasil observasi terhadap aspek yang diamat yang telah disesuaikan dengan tahapan model pembelajaran Mind Mapping. Pada saat siklus pertama siswa masih terlihat pasif pada saat pembelajaran berlangsung, hanya beberapa siswa yang dapat merespon guru. Keaktifan siswa mulai terlihat pada pembelajaran siklus ke dua. Hal tersebut terlihat dari jumlah peserta didik yang memberikan respon kepada guru walaupun masih terdapat beberapa siswa yang pasif. Dan pada siklus ke tiga hampir seluruh siswa berperan aktif memberikan respon pada guru ketika proses pembelajaran berlangsung, sehingga suasan belajar lebih kondusif, menyenagkan dan siswa tidak jenuh dan yang lebih penting perhatian siswa berfokus kepada arahan guru baik dalam memaparkan materi ajar perihal gaya, maupun pada saat proses percobaan 
berlangsung. Hal tersebut tidak terlepas dari usaha guru dalam memperbaiki pembelajaran pada setiap siklusnya, sehingga siswa lebih antusias dan termotivasi pada saat proses pembelajaran berlangsung.

Kedua, Terdapat peningkatan penguasaan konsep siswa dalam pembelajaran IPA pada materi gayaa pada seiswa setelah menerapkan model pembelajaran Mind Mapping. Hal itu berdasarkan Tabel 4.32 dapat diperoleh perbedaan persentase dari siklus satu sampai siklus III. Persentase pada saat siklus satu mencapai $80 \%$ dengan nilai rata-rata 74,45 dan pada siklus dua persentase mencapai $85 \%$ dengan nilai rata-rara 87,5 dan pada siklus tiga persentase mencapai 95\% dengan rata-rata 92,5. Sehingga dapat disimpulkan bahwa terdapat peningkatan kemampuan pemahaman konsep siswa pada saat proses pembelajaran dengan menggunakan model Mind Mapping.

\section{DAFTAR RUJUKAN}

Arnyana, I. (2007). Pengembangan Peta Pikiran untuk meningkatkan kecakapan berpikir kreatif siswa. Journal Pendidikan dan Pengajaran UNDIKSHA 1(2). Hlm 676.

Kusmintayu, N. (2012). Penerapan model Mind Mapping untuk meningkatkan keterampilan berbicara pada siswa Sekoah Menengah Pertama. Journal Penelitian Bahasa. Sastra Indonesia dan Pengajarannya.1 (2).hlm 100.

Mulyasa, E. (2011). Kurikulum Tingkat Satuan Pendidikan. Bandung: Remaja Rosdakarya

Rustman, dkk.(2011). Pembelajaran Berbasis Teknlogi Informasi dan Telekomunikasi

Samatowa. (2011). Pembelajaran IPA di Sekolah Dasar. Jakarta: Indeks

Sumaya. (2014). Sains di SD. Bandung: Erlangga

Shoimin, Aris. 68 Model Pembelajaran Inovatif dalam Kurikulum 2013. Yogyakarta: ARRUZZ MEDIA

Swadarma, Doni. (2013). Penerapan Mind Mapping dalam Kurikulum Pembelajaran. Jakarta: PT Elex Media Komputindo

Trianto. (2007). Model Pembelajaran Inovatif Berorientasi Kontruktivistik. Jakarata: Prestasi Pustaka.

UU RI No 20 Tahun 2003. (2006). Tentang SISDIKNAS. Bandung: Citra Umbaran

Wisudawati, A.W. (2014). Metodologi Pembelajaran IPA.Yogyakarta: Bumi Aksara 